\title{
Applying Output-drive, Input-enabled Hypothesis in College Students' Intercultural Communication Competence: A Case Study of Sichuan University of Arts and Science*
}

\author{
He Wei \\ Sichuan University of Arts and Science, Dazhou, China
}

\begin{abstract}
Nowadays, globalization has already changed the whole world than anyone could imagine. China adopts an open mind to the change for globalization, and spares no effort to participate in international economic cooperation, which means more opportunities for Chinese students to study and work abroad. Therefore, it is not necessary but a must to cultivate college students' intercultural communication competence. This paper is to conduct a survey in Sichuan University of Arts and Science, involving 180 non-English Major freshmen. By the combination of qualitative and quantitative analysis, this paper is to discuss the problems existing in the process of cultivating college students' intercultural communication competence, such as: insufficient output of students' language competence, and inadequate input of culture knowledge ,and probe into the reasons for those problems. Meanwhile, this paper also put forward some solutions about how to cultivate college students' intercultural communication competency with the perspective of output--driven, Input--enabled Hypothesis.
\end{abstract}

Index Terms -intercultural communication competence, output--driven, input--enabled Hypothesis, college English teaching, culture

\section{INTRODUCTION}

How to communicate with people from different cultural backgrounds? In the past, only diplomats, expatriates, and transnational travelers need to consider this problem. With the rapid development of society, especially the appearance of globalization, people in long distance are drawing closer to each other. Almost no country is made up of single nation and single culture; consequently, people will communicate with people from different cultures every day. After reform and opening up policy, China spares no effort to participate in international cooperation, and joined the WTO in 2001. Later, many multinational companies have established branches in China, offering a large number of jobs to people from different countries; meanwhile, many Chinese get the opportunities to study and work abroad. However, because of different social backgrounds, social systems, and customs, people have difficulties in understanding and communicating with each other (Petrakis, 2013). Although learning a foreign language, especially English is the best way to solve this problem, language learning and culture learning cannot be separated, as Mak (2010) asserted that language learning is a deep, conceptual activity which involves explicit analysis of language and culture. According to Milena (2017), understanding the ways in which culture shapes our attitudes about ourselves and others, developing critical awareness of ethnic, racial, gender and other inequalities and discrimination, and strengthening of individual responsibility, sensitivity and solidarity are essential in order to respect each culture for the development of humankind.

The key to make them understand each other is to get to know each others' different cultures, therefore, culture learning is not a necessity but a must for a foreign language learner to obtain intercultural communication competence. However, until now it is still very hard to give a unanimous definition of Intercultural communication, and many scholars offer their own definition of this term. Stella Ting-Toomy (1999) offers her understanding of this term in her book Communicating Across Culture:"Intercultural communication is viewed as a symbolic exchange process between persons of different cultures. The general goal of effective intercultural communication is to create shared meanings between dissimilar individuals in an interactive situation". Then, what is intercultural communication competence, for Janet and Milton Bennett, intercultural communication competence is the ability to communicate effectively in cross-cultural situations and to relate appropriately in a variety of cultural contexts (Schoeffel, 2014).

Nowadays, English has already become the most widely used language in the world. Therefore, English has become one of the required courses for contemporary Chinese college students. The intercultural communication competence of Chinese college students is the combination of English teaching and communication competence acquisition. General

\footnotetext{
* Sponsored By: Sichuan Foreign Language and Literature Research Center and Shanghai Foreign Language Education Express "Applying Output-Drive, Input-Enabled Hypothesis in College Students' Intercultural Communication Competence: A Case Study of Sichuan University of Arts and Science" NO.SCWYH17-14
} 
Office of the Ministry of education issued College English curriculum requirements in July 2007 which pointed out that College English teaching in China was an integrated teaching system, at the guide of foreign language teaching theory, with English language knowledge and practical skills, and intercultural communication as the main content, together with a variety of teaching methods and teaching strategies (General Office of the Ministry of education, 2007). From curriculum requirements, it is not difficult to see that the cultivation of intercultural communication competence of college students should be one important goal of contemporary college English teaching. So how is the intercultural communication competence of current college students? And how to cultivate their intercultural communication competence effectively?

The paper is to analyze the problems in the process of cultivating college students' intercultural communication competence and probes into the reason for those problems, based on the survey conducted in Sichuan University of Arts and Science which involved 180 non-English freshman. The Survey objectives are to find the problems existing in the process of cultivating students' intercultural communication competence, and suggest solutions with the perspective of "Output- Drive, Input-Enabled Hypothesis".

\section{Methodology And Survey Date Analysis}

This thesis conduct a survey in the form of questionnaire, involving 180 non-English freshmen of Sichuan University of Arts and Science who are chosen randomly. By the combination of quantitative and qualitative analysis method, the date from questionnaire are analyzed to get to know the basic situation of the intercultural communication competence of the freshmen in Sichuan University of Arts and Science, furthermore, get a glimpse of the intercultural communication competence of Chinese college students of and offer suggestions to those problems.

\section{A. Research Objective and Participator}

The research objectives are to analyze: 1). current college students' intercultural communication competence of Sichuan University of Arts and Science; 2). problems existing in the formation of intercultural communication competence and reasons for those problems; 3). the cultivation method of intercultural communication competence for Chinese college student.

This survey is conducted in the form of questionnaire. Questionnaires were distributed to 180 non-English major freshmen from Sichuan University of Arts and Science chosen randomly. All participators have already acquired certain English language ability because they have already learned English 7 or 10 year before entering College.

\section{B. Research Methodology}

This research employs both qualitative and quantitative analysis methods. The questionnaire is divided into four parts, and includes 29 questions, with the hope of exploring students' intercultural communication awareness, language competence, intercultural attitude, and intercultural communication competence. In this survey, 180 questionnaires are distributed, and 172 valid questionnaires are collected, and the recovery rate is $95.5 \%$. All participators are anonymous. All those strategies ensure that the data from questionnaire are credible.

\section{Analysis of Survey Data}

1. Evaluation and Analysis of Intercultural Communication Awareness

There are 4 questions in this part, which evaluates students' intercultural communication awareness.

TABLE 1

PARTICIPATOR's RESPOND ON THE ATTITUDE ABOUT INTERCULTURAL COMMUNICATION

\begin{tabular}{|l|l|}
\hline A. Strong will to have intercultural communication experience & $44 \%$ \\
\hline B. Want to have intercultural communication experience & $26 \%$ \\
\hline C. Refuse to have intercultural communication experience & $6 \%$ \\
\hline D. Not sure & $24 \%$ \\
\hline
\end{tabular}

TABLE 2

PARTICIPATOR'S RESPOND ON PERSONAL ABROAD EXPERIENCE

\begin{tabular}{|l|l|}
\hline A. With abroad experience & $5 \%$ \\
\hline B. Without abroad experience & $95 \%$ \\
\hline
\end{tabular}

As seen from Table 1, most participators are looking forward to have intercultural communication with people from American and Britain (70\%), and 26\% participators have strong desire to experience intercultural communication. While only few participators refuse to have that experience (6\%).24\% participators are not sure if they want to interact with people with different cultural background. The low degree of disagreement shows the necessity of offering more opportunities for student to have intercultural experience.

Generally Speaking, from table 2, most participators have no abroad experience, and only 5\% of them have overseas experience. The surface reason for this is that school authorities don't provide enough abroad projects to meet students' needs. However, after a second thought, the deep reason is that if they want to participate in those projects, the ability of communication in English is a must, while most of them are lack of this ability. The examination-oriented education in 
senior high school makes Chinese students focus on reading and writing, and ignore listening and speaking. However, listening and speaking weigh more than reading and writing in cross-cultural communication. Although many participators have already accumulated large vocabulary and mastered important English grammar before entering University, they still find it is very difficult to communicate in English. In intercultural communication, they can only use simple words like "Thank you", "Goodbye" to have daily communication, and nothing more than that.

2. Evaluation and Analysis of English Language Competence

There are 5 questions in this part, which evaluates students' four comprehensive ability of listening, speaking, reading and writing.

TABLE 3

PARTICIPATORS RESPONSE ON LISTENING COMPREHENSION

\begin{tabular}{|l|l|}
\hline A. completely lost of track of the radio programmer and TV series & $55 \%$ \\
\hline B. Get a part of the radio programmer and TV series & $35 \%$ \\
\hline C. Not sure & $10 \%$ \\
\hline
\end{tabular}

TABLE 4

PARTICIPATORS RESPONSE ON ORAL ENGLISH COMPREHENSION

\begin{tabular}{|l|l|}
\hline A. Have Difficulty in using English to express himself & $42 \%$ \\
\hline B. Not sure & $46 \%$ \\
\hline C. With the ability to use English to express himself & $12 \%$ \\
\hline
\end{tabular}

TABLE 5

PARTICIPATORS RESPONSE ON READING COMPREHENSION

\begin{tabular}{|l|l|}
\hline A. With the ability to read English Newspaper and Magazine without referring to dictionary & $7 \%$ \\
\hline B. Not sure & $30 \%$ \\
\hline C. Have Difficulty in reading English Newspaper and Magazine without referring to dictionary & $63 \%$ \\
\hline
\end{tabular}

Table 3 demonstrates that most participators are lack of the necessary listening ability, because they (count for 55\%) agree that they cannot follow the radio program and TV series from Britain and America. At the same time, and 35\% of them are not sure whether they can or not. The reason behind this data is that students are short of basic listening training.

From Table 4, it is easy to see that $42 \%$ participators agree that they cannot express themselves clearly in English, and $46 \%$ of them are not sure about it. The reason behind this data is that English teaching in China gives priority to vocabulary and grammar for long time, which makes teachers spend much time in explaining vocabulary and grammar in class, and give after-class exercises to strengthen their language knowledge acquired in class. This teaching mode causes many English teachers emphasize the input of linguistic knowledge, but neglect to create opportunities for students to use language in simulated language environment, that is, the output of language. This kind of teaching mode ignores the essence of language learning. Consequently, teachers tend to equate English learning with vocabulary and grammar learning. Students take notes in class, and memorize words and grammar after class. For long time, this teaching mode of emphasizing input and ignoring output makes students unable to use English in language environment.

Table 5 demonstrates that more than half of the participators agree that they cannot read English newspapers and magazines without dictionaries and other auxiliary tools(count for 63\%), at the same time, 30\% participators are not sure whether they can or not. Only $7 \%$ of them can read English newspapers and magazines without dictionaries .The reason for this phenomenon is that when explaining words in class, teachers pay attention to the denotation and ignore the connotation, in other words, the cultural background behind word? However, it is the connotation of a word that makes a sentence difficult to understand. So when reading the original English newspapers and magazines, participators find that they cannot really understand the meaning of the article even there are no new words.

3. Evaluation and Analysis of Intercultural Communication Attitude

There are 7 questions in this part used to evaluate participators' intercultural communication attitude.

TABLE 6

PARTICIPATORS' ATTITUDE TOWARDS INTERCULTURAL COMMUNICATION

\begin{tabular}{|l|l|}
\hline A. Interested in other countries lifestyles and willing to communicate with people from other cultures & $86 \%$ \\
\hline B. Avoid communicating with people other cultures & $5 \%$ \\
\hline C. Not Sure & $9 \%$ \\
\hline
\end{tabular}

As seen from table 6, most participators agree that they are interested in other countries' lifestyles and values (count for $86 \%$ ). They long to communicate with people from different cultures. Only 5\% of them avoid intercultural communication. The above data show that the vast majority of them have a positive attitude towards intercultural communication, looking forward to enjoying their intercultural communication. More than half of the participators respect their counterpart's ideas in the process of intercultural communication, and willing to their behaviors to adapt to their counterpart's culture, at the same time they try to avoid prejudice and Prejudice in the process of intercultural communication. The above data indicate that most participators are with intercultural awareness. They are aware of the difference between their culture and other cultures, and willing to encounter these differences in an open manner. 
4. Evaluation and Analysis of Intercultural Communication Competence

There are 12 questions in this part used to evaluate participators' intercultural communication competence.

TABLE 7

PARTICIPATORS' RESPONSE OF INTERCULTURAL COMMUNICATION KNOWLEDGE

\begin{tabular}{|l|l|}
\hline A. Do not know what to say in intercultural communication & $19 \%$ \\
\hline B. Know what to say in intercultural communication & $5 \%$ \\
\hline C. Not Sure & $76 \%$ \\
\hline
\end{tabular}

TABLE 8

PARTICIPATORS' RESPONSE TO WESTERN CUSTOM

\begin{tabular}{|l|l|}
\hline A. Know nothing about Western Custom & $84 \%$ \\
\hline B. Have a good understanding of Western Custom & $9 \%$ \\
\hline C. Do no care & $7 \%$ \\
\hline
\end{tabular}

TABLE 9

PARTICIPATORS' RESPONSE TO WESTERN NON-VERBAL COMMUNICATION

\begin{tabular}{|l|l|}
\hline A. Know nothing about Western Non-Verbal Communication & $74 \%$ \\
\hline B.Have a good understanding of Western Non-Verbal Communication & $20 \%$ \\
\hline C. Not Sure & $6 \%$ \\
\hline
\end{tabular}

TABLE 10

PARTICIPATORS' RESPONSE TO WESTERN SPACE LANGUAGE

\begin{tabular}{|l|l|}
\hline A. Know nothing about Western Space Language & $53 \%$ \\
\hline .
\end{tabular}

B. Have a good understanding of Western Space Language $127 \%$

\begin{tabular}{l|l} 
C. Not Sure & $20 \%$ \\
\hline
\end{tabular}

As seen from table 7, 19\% participator do not know what to say in intercultural communication, and $76 \%$ of them are not sure if they know what to say in intercultural communication. The above data show that most participators are without the ability to have intercultural communication. Because non-English teaching in Colleges is still examination-oriented, teachers focus on explaining language knowledge, ignoring the culture behind language, especially the culture and custom in intercultural communication. Students are used to memorizing vocabulary and the rules of grammar, and do not pay attention to the cultural knowledge related to intercultural communication.

From table 8, 9 and 10, it is not difficult to see 84\% participators don't know western customs, and $74 \%$ of them don't know western non-verbal communication, meanwhile, 53\% of them have no idea of the appropriate body distance in western culture. The above data show that most of them have not mastered the related knowledge of intercultural communication, and the reasons for those problems result from teachers' misunderstanding of English teaching goal. Their interpretation of English as grammar and vocabulary learning makes them ignore the essence of language teaching, a tool for communication. Consequently, they do not realize the importance of cultivating college students' intercultural communication competence.

Language is the carrier of culture, so it cannot be talked without culture. In language and culture, English education experts Deng Yanchang, Liu Runqing(1998) said that learning a foreign language not only need to master the pronunciation, grammar, vocabulary and idioms, but also need to know the way they use to look at things, to observe the world; and the way they use to reflect the thought, habits and behavior of their society. Nowadays, most college students can speak English, but that does not mean that they can use English to have intercultural communication, because language competence is just a part of intercultural communication competence. Although some teachers have already realized the importance of imparting cultural knowledge, they are still unable to impart enough culture education that because they are lack of cultural knowledge.

\section{Suggestion on Cultivation of College Students' Intercultural Communication Competence at the PERSPECTIVE OF OUTPUT-DRIVE, INPUT-ENABLED HYPOTHESIS}

Professor Wen Qiufang, from Chinese foreign language education research center of Beijing Foreign Studies University, proposed a new hypothesis "Output- Drive, Input-Enabled Hypothesis" in foreign language teaching. In this new hypothesis, output is defined as the drive of language acquisition, and also the objective of language acquisition; while input is defined as the mean to complete the task output and lay foundation for possible language output in the future, rather than simply as the ability to understand and accept knowledge. (Wen Qiufang, 2014) This paper is to discuss the training method of intercultural communication for college students from the perspective of this new Hypothesis.

\section{A. Introduce Cultural Knowledge into Class Teaching}

After fully aware of the importance of cultural education in cultivating college students' intercultural communication, teacher should adjust teaching content intuitively; instead of just focusing on language knowledge explanation in the class, they should introduce language knowledge into class teaching. Because in the process of intercultural communication, many misunderstandings arise from people's different understanding of the same word for the same 
word may contain opposite connotation. Therefore, teachers should guide students to understand the connotation of English vocabulary, that is, the loaded cultural meaning of word. Chinese are proud of being the descendants of dragon, because dragon is the symbol of power in traditional China culture. However dragon is the symbol of evil in western culture, like the one depicted in the England Epic poem Beowulf, Beowulf lead his people to kill the evil warrior dragon in attempt to defend their home. If students understand the different cultural connotation of the same word in China and Western countries, they will know why Westerners fell puzzled when Chinese call themselves the successors of dragon. There are huge differences in the use of color in China and western countries. For example, red is the symbol of happiness in China, a color often used in Wedding occasion, while in western countries, white symbolizes purity and innocence, a color often used in Wedding occasion. If lack of those cultural differences, they are easy to misuse color words in intercultural communication, which may cause conflicts during intercultural communication. What's more, there are many words from the Bible, Greek mythology and literary masterpieces in English. Only with the knowledge of the cultural connotation behind these words, students can use these words in intercultural communication properly. At the same time, there are differences in the choice of topic for daily communication in different countries. Westerners prefer to talk about weather, sports, and pets, while seldom mention family, income and other sensitive private topics. Chinese is willing to talk about family, income, children, while seldom mention disease, death. Therefore in the process of intercultural communication, students must be careful when it goes to choose appropriate topics; otherwise it is likely to lead to the failure of intercultural communication.

\section{B. Combine the Methods of Input and Output in Culture Acquisition}

Many English learners believe that language acquisition must be based on a large number of listening and speaking practice, which also goes to the acquisition of culture knowledge. Therefore, many English learners believe that the best way to acquire culture knowledge is to listen to teacher attentively in class, read novels, magazines in English version or watch original English movies after class. Obviously, a large number of culture knowledge input, especially reading novels in English version, watching original English movies can arouse students' enthusiasm to culture acquisition, but there is a big difference between the acquisition of culture knowledge and intercultural communication competence, that is to say, culture knowledge acquisition does not mean that students can use those knowledge properly in intercultural communication, as social and cultural school believes that foreign language learning should not separate learning and application, and learning should be integrated into the acquisition and utilization of culture knowledge(Firth, A \& J. Wagner, 2007). Teacher should not only explain the cultural knowledge in class teaching, but also provide practice opportunities for students to output their acquired culture knowledge, in this way; students can obtain the intercultural communication competence. Otherwise, the culture knowledge acquired by students will only be the knowledge in their mind, for it never has the chance to be used in the actual language environment. For example, teacher can divide the whole class into 4 groups, each group with 10 students, and then assign different intercultural communication tasks to each group, such as 1) your boss send you to airport to meet your potential customers, how to communicate with them; 2) you take part in an international business negotiation in representation of your company, how to invite the other party to have dinner the end of the negotiations, and how to choose the appropriate topic at dinner; 3) you want to invite foreign teacher to go to a restaurant, how to invite him; 4) imagine you study abroad as an exchange student, during the spring festival you want to invite some foreign friends to dinner at home, how to prepare this gathering. After assigning different tasks, teacher can take 3-5 minutes to describe each task in detail and make a brief introduction of relevant background knowledge. Each group is given 10 minutes to prepare. They can allocate each one's role at their own will and collect data for simulated situation practice. Finally, teacher should give each group 5-6 minutes to perform their intercultural communication task in front of all students. Then teacher should give his own comments, point out the problems in student's intercultural communication performance, and put forward methods for improvement. After class, teachers should arrange appropriate simulated situation training to enable students to further consolidate their acquired culture knowledge

\section{Cultivate Students' Consciousness of Intercultural Communication}

Students are the recipient of intercultural communication. Therefore, their ideal of English learning should be changed, that is to say, they shouldn't simply equate English learning with examination. College student need to know that the acquisition of intercultural communication competence is an important part of language learning. Meanwhile, they should realize why people from different areas have different customs, custom and value is because they have different cultures. Therefore, when interacting with people from different places, if they do not have culture awareness to tolerant those cultural differences, they will fail in cross-cultural communication. College student should put themselves and others on an equal position, learn to stand in others' position to think problems in intercultural communication. For example, when Chinese people having meals with friends, they usually rush to pay the bills to show their hospitality, while foreigners will be surprised to see this and feel puzzled why most Chinese are so eager to pay bill. Because when foreigners eat together, they like to split the bill and pay their own part, which makes Chinese feel they lose face. Therefore, if they don't know the difference between others and themselves, Chinese people will feel that foreigners are too mean, and Foreigners will think Chinese are so strange.

\section{CONCLUSION}


The ultimate goal of College English Teaching is to cultivate college students' intercultural communication competence, which is also the most important language ability in the new era. Therefore, university teacher, as the organizer of foreign language teaching, should give up traditional teaching method, give priority to cultivating students' intercultural communication competence in their teaching, improve teaching methods, adjust teaching contents, and provide more opportunities for students to practice their intercultural communication competence. Secondly, teacher shouldn't stop their way of absorbing the knowledge of culture from other countries in order to impart enough culture knowledge to students in class. Finally, as the recipient of intercultural communication competence, students should be open to cultural differences, cultivate their cultural awareness, and participate in intercultural communication practice actively.

\section{REFERENCES}

[1] Deng Yanchang, Liu Runqing. (1998). Language and Culture. Beijing: Foreign Language Teaching and Research Press.

[2] Firth, A \& J. Wagner. (2007). Second/foreign language learning as a social accomplishment: Elaborations on a conceptualized SLA. The Modern Language Journal, 91:800-819.

[3] General Office of the Ministry of education. (2007). College English curriculum requirements. Shanghai: Shanghai Foreign Education Press.

[4] Mak, A. S. (2010). Enhancing academics' capability to engage multicultural classes and internationalize at home. International Journal of Teaching and Learning in Higher Education, 3: 365-373.

[5] Petrakis, P. E., \& Kostis, P.C. (2013). Economic Growth and Cultural Change. Journal of Socio-Economics, 47: $147-157$.

[6] Schoeffel, V. (2014). How to facilitate meaningful interreligious dialogue: an exploration of potential contributions from intercultural communication theory. University Salzburg.

[7] Ting-Toomey, S. (1999). Communicating Across Cultures. Guilford:The Guilford Press.

[8] Tomic,M D. (2017). Why Teachers need to know about intercultural communication. Journal Plus Education, 1:262-275.

[9] Wen Qiufang. (2014). "Output- Drive, Input-Enabled Hypothesis: Experiment on Forming College Foreign Language Teaching Theory. Journal of Link and Think, 2,:8-14.

He Wei was born in Sichuan, China in 1982. She received her master degree in Literature from Sichuan University, China in 2010. She is currently a lecturer in School of Foreign Department, Sichuan University of Arts and Science, Sichuan, China. Her research interests include English and American Literature., and intercultural communication. 